WETLANDS, Vol. 24, No. 1, March 2004, pp. 23-42

(C) 2004, The Society of Wetland Scientists

\title{
VEGETATION OF UPPER COASTAL PLAIN DEPRESSION WETLANDS: ENVIRONMENTAL TEMPLATES AND WETLAND DYNAMICS WITHIN A LANDSCAPE FRAMEWORK
}

\author{
Diane De Steven] and Maureen M. Toner ${ }^{2}$ \\ ${ }^{1}$ USDA Forest Service, Southern Research Station \\ Center for Forested Wetlands Research \\ 2730 Savannah Highway \\ Charleston, South Carolina, USA 29414 \\ E-mail: ddesteven@fs.fed.us \\ ${ }^{2}$ New Brunswick Department of Natural Resources and Energy \\ Box 6000 \\ Fredericton, New Brunswick, Canada, E3B 5HI
}

\begin{abstract}
Reference wetlands play an important role in efforts to protect wetlands and assess wetland condition. Because wetland vegetation integrates the influence of many ecological factors, a useful reference system would identify natural vegetation types and include models relating vegetation to important regional geomorphic, hydrologic, and geochemical properties. Across the U.S. Atlantic Coastal Plain, depression wetlands are a major hydrogeomorphic class with diverse characteristics. For 57 functional depression wetlands in the Upper Coastal Plain of South Carolina, we characterized the principal vegetation types and used a landscape framework to assess how local (wetland-level) factors and regional landscape settings potentially influence vegetation composition and dynamics. Wetland sites were stratified across three Upper Coastal Plain landscape settings that differ in soils, surface geology, topography, and land use. We sampled plant composition, measured relevant local variables, and analyzed historical transitions in vegetative cover types. Cluster analysis identified six vegetation types, ranging from open-water ponds and emergent marshes to closed forests. Significant vegetation-environment relationships suggested environmental "templates" for plant community development. Of all local factors examined, wetland hydrologic regime was most strongly correlated with vegetation type, but depression size, soil textural type, and disturbance history were also significant. Because hydrogeologic settings influence wetland features, local factors important to vegetation were partly predictable from landscape setting, and thus wetland types were distributed non-randomly across landscape settings. Analysis of long-term vegetation change indicated relative stability in some wetlands and succession in others. We developed a landscape-contingent model for vegetation dynamics, with hydroperiod and fire as major driving variables. The wetland classification, environmental templates, and dynamics model provide a reference framework to guide conservation priorities and suggest possible outcomes of restoration or management.
\end{abstract}

Key Words: Carolina bay, depressional wetlands, environmental gradients, hydrogeologic setting, hydroperiod, landscape, reference wetlands, wetland management, restoration, vegetation types

\section{INTRODUCTION}

Reference wetlands (Brinson and Rheinhardt 1996) play an important role in wetland protection and in assessing the condition of restored or created wetlands. Because wetlands are inherently variable, use of a single reference site as a standard for comparison is problematic. Rather, it is desirable to have "reference systems" that encompass the natural diversity of intact, functional sites (Clewell and Lea 1990, Smith et al. 1995, Palik et al. 2000). A starting framework for characterizing wetland diversity is provided by hydro- geomorphic (HGM) classes (riverine, flat, etc.) and by the concept that hydrogeologic (landscape) settings influence wetland hydrologic regimes, substrates, and chemistry (Brinson 1993, Bedford 1996). Within this broad framework, regionally-based reference data are needed. Since plant species composition often expresses the influence of many ecological factors, vegetation is an important attribute for assessing wetland status, conservation objectives, and restoration performance. Thus, for a given HGM class, a reference system would describe the range of natural vegetation types and would also include models that relate vegetation 
composition and temporal dynamics to important site variables and regional landscape settings (e.g., Kirkman et al. 2000, Godwin et al. 2002).

The U.S. Atlantic Coastal Plain province contains numerous isolated depression wetlands, including Carolina bays and other smaller features referred to variously as Grady ponds, Citronelle ponds, and/or limesinks. Collectively, these depressions have varied morphology and geologic origins (e.g., Folkerts 1997, Lide 1997, Ewel 1998, Kirkman et al. 2000), but as a regional HGM type, they function in similar ways ecologically. Their hydrologic regimes are driven by rainfall and evapotranspiration, although some depressions may also receive inputs from shallow ground water (Schalles and Shure 1989, Lide et al. 1995, Chmielewski 1996). They are influenced by natural disturbances such as periodic drought and wildfire (Sharitz and Gresham 1998). Coastal Plain depression wetlands provide critical habitat for semi-aquatic flora and fauna, particularly herpetofauna (Semlitsch and Bodie 1998, Kirkman et al. 1999, Taylor et al. 1999, Edwards and Weakley 2001). Historically, over $80 \%$ of these wetlands may have been degraded severely or lost entirely through ditching, draining, timbering, and agricultural uses (Bennett and Nelson 1991). Consequently, they have been a focus of regional conservation and restoration efforts, and concern about further loss has been heightened following a recent court decision restricting federal regulation of isolated wetlands (Environmental Law Institute 2001). We studied Coastal Plain depressions with the aim of characterizing the natural vegetation types and providing a reference framework for conservation and management applications.

In the semi-arid climates of the North American Great Plains region, depressional complexes such as prairie potholes and playa wetlands have predominantly herbaceous vegetation types (Kantrud et al. 1989, Haukos and Smith 1994). In humid Coastal Plain climates, by contrast, depression vegetation is more varied and can range from aquatic and emergent communities to shrub pocosins and closed forests (Bennett and Nelson 1991, Sharitz and Gresham 1998). This variation has presented a challenge for understanding what factors determine wetland vegetation composition. Hydrology is assumed to be the primary controlling process, but few published studies have systematically quantified vegetation-environment relationships in Coastal Plain depressions (e.g., Kirkman et al. 2000). Depression vegetation will be directly influenced by local (wetland-level) factors such as the hydrologic regime, soil type, wetland size, and site disturbance history. Vegetation will also be dynamic if local factors change over time. However, local factors are influenced by regional landscape settings, which not only shape wetland hydrogeologic features but also affect natural disturbance regimes and land uses (Kirkman et al. 1996, 2000). Thus, landscape settings may indirectly influence wetland vegetation by shaping the expression of local factors.

We describe research to identify important vegetation-environment relationships and temporal dynamics for Coastal Plain depression wetlands. Using a hierarchical landscape framework, we studied functional wetland sites within a defined physiographic region, the Upper Coastal Plain subdivision of the South Atlantic Coastal Plain. Within the Upper Coastal Plain, we identified major ecological landscape settings (land types) in which depressions occur. For 57 wetlands distributed across these landscape settings, we characterized major vegetation types at the wetland scale (similar to the approach of Stewart and Kantrud 1971 for prairie potholes). We measured relevant site-level variables and analyzed transitions in vegetative cover type from historic conditions to the present. We addressed three questions. 1) What local environmental factors potentially influence vegetation composition'? 2) To what extent does landscape setting predict the local factors relevant to vegetation? 3) How do local factors or landscape settings influence longer-term vegetation dynamics? We synthesized the findings into qualitative models that provide a starting point for predicting wetland distribution and dynamics. We then suggest how these models can provide a regional reference framework for guiding depression wetland conservation efforts and assessing possible outcomes of restoration or management.

\section{METHODS}

\section{Landscape Settings and Site Selection}

The study region was the western half of the South Carolina Upper Coastal Plain, an area encompassing roughly 10 counties. In this humid subtropical climate, forests are the predominant natural ecosystems (Bailey et al. 1994). Forest composition varies as a function of land relief, soil moisture and fertility, and fire frequency; the principal types are pines (Pinus taeda, $P$. elliottii, $P$. palustris) or mixed pine-hardwoods including oaks (Quercus spp.), hickories (Carya spp.), sweetgum (Liquidambar styraciflua), a n d blackgum (Nyssa sylvatica) (Jones et al. 1984, Workman and McLeod 1990). Agriculture (including row crops, fruit orchards, and grazing pastures) and forestry are the primary land uses across the region.

As the basis for a landscape approach, we divided the Upper Coastal Plain study region into three ecological land types (landscape settings) based on the distribution of similar upland soil types, surface ge- 
Table 1. Principal features of three Upper Coastal Plain landscape settings (land types) in which depression wetlands occur. Elevations ( $\mathrm{m}$ above mean sea level) of the study wetlands are given to illustrate general differences in landform topographic position.

\begin{tabular}{|c|c|c|c|}
\hline \multirow[b]{2}{*}{ Feature } & \multicolumn{3}{|c|}{ Landscape Setting" } \\
\hline & Sandhills & Loam Hills & Large River Terraces \\
\hline Predominant upland soils ${ }^{\mathrm{b}}$ & $\begin{array}{l}\text { Quartzipsamments and Gross- } \\
\text { arenic Paleudults }\end{array}$ & Typic and Arenic Paleudults & $\begin{array}{l}\text { Aquic Paleudults and Aeric } \\
\text { Aquults }\end{array}$ \\
\hline Upland soil profile features & sandy to depth $\geq 122 \mathrm{~cm}$ & $\begin{array}{l}\text { sand or loamy sand to depth } \\
<122 \mathrm{~cm} \text { over sandy clay } \\
\text { loam or clayey subsoils }\end{array}$ & $\begin{array}{l}\text { sandy-loamy and somewhat } \\
\text { poorly drained, often with } \\
\text { clayey subsoils }\end{array}$ \\
\hline Surficial geologic units' & Dune Sand and Barnwell Group & Upland (Citronelle) & Quaternary alluvium \\
\hline Land relief & $\begin{array}{l}\text { undulating to moderately dis- } \\
\text { sected }\end{array}$ & $\begin{array}{l}\text { undulating to moderately dis- } \\
\text { sected }\end{array}$ & nearly level \\
\hline $\begin{array}{l}\text { Median elevation (range) of } \\
\text { wetland sites }\end{array}$ & $76 \quad(49-M)$ & $91(52-195)$ & $43(37-55)$ \\
\hline $\begin{array}{l}\text { Probable hydrologic inputs to } \\
\text { depression wetlands }\end{array}$ & precipitation (groundwater?) & precipitation & precipitation and groundwater \\
\hline
\end{tabular}

a Landscape names follow usage of Myers et al. 1986.

U.S. soil taxonomy system (Soil Survey Staff 1975).

- Sources: Doering 1960, Myers et al. 1986, Nystrom et al. 1986, Prowell 1994.

"From Chmielewski 1996.

ology, and physiography (Table 1). "Sandhills" are uplands of moderate relief with deep and droughty sands, "Loam Hills" are moderately-dissected uplands of loamy sands with finer-textured subsoils, and "Terraces" are level, relict river terraces with somewhat poorly drained soils that are often clayey. Of the three landscape settings, the well-drained and more fertile Loam Hills uplands have historically supported the most extensive agriculture (Myers et al. 1986). Depression wetlands occur within each landscape. In the Sandhills and Loam Hills, depressions are generally found on broad interfluvial ridges, whereas they are scattered throughout the low-relief Terraces. Because of lower relative landscape elevations (Table I), Terrace depressions are more likely to have hydrologic regimes influenced by shallow ground water than depressions in other landscape settings (Chmielewski 1996). As a group, Upper Coastal Plain depressions typically have mineral soils and arc relatively small, whereas the larger Carolina bays of the Lower Coastal Plain can also have organic soils (Bennett and Nelson 1991).

We used contemporary aerial photographs (falsecolor infrared, 1: 15,840 or 1:20,000 scale) to chose a quasi-random sample of functional wetlands for study, with selection partially constrained by site accessibility. The sample included 35 sites (hereafter, "SRS wetlands") on the $800 \mathrm{~km}$ ' Savannah River Site (SRS), a National Environmental Research Park containing former nuclear facilities of the US Department of Energy, plus 22 sites (hereafter, "regional wetlands") on private or state-owned lands across eight counties surrounding the SRS. In each group (SRS and regional), sites were stratified across the three land- scape settings. The regional group included an accessible site on the adjacent Middle Coastal Plain; for analysis, we assigned this site to the "Terrace" landscape based on similar soil and landform features. Collectively, the 57 wetlands spanned the typical size range (area 0.4-20 ha) of Upper Coastal Plain depressions (Schalles et al. 1989).

The SRS is a protected area where the dominant land use is managed pine forests. The SRS study wetlands have received relatively little new disturbance since the early $1950 \mathrm{~s}$ (see Temporal Vegetation Change below); thus, their current plant composition represents decades of succession and a development trajectory reflective of current hydrologic and landscape conditions. In the wider region where land use is more varied (agriculture and forestry), depression wetlands either are severely altered from chronic disturbance or appear relatively intact and functional (Bennett and Nelson 199 I). We expected that choosing functional regional wetlands would provide sites of comparable status to the SRS wetlands, and we could test whether species composition differed between the two groups in any obvious ways.

\section{Vegetation Sampling and Classification}

Large Carolina bays can have distinct interior plant zonation (Schalles et al. 1989), but vegetation in smaller depressions may be more patchy and is often fairly homogeneous. To characterize plant composition at the wetland scale, we used a line-intercept method similar to transect-based point sampling (Rader and Shiozawa 2001). In each wetland, we established one line transect spanning the depression long axis and two 
transverse transects crossing the long axis at $1 / 3$ and $2 / 3$ of its length (similar to Porcher 1966). To minimize sampling any upland-wetland ecotone, transect endpoints were located $20 \mathrm{~m}$ in from the depression perimeter, which was identified by a combination of a topographic rise indicative of a basin rim and location beyond extreme high water lines on trees. Species presence was recorded in vertical projections of $1-\mathrm{m}$ line segments spaced every IO $\mathrm{m}$ along each transect. In each line segment, species presence was recorded separately in three height strata (ground/shrub layer, mid-story, and canopy overstory). Any other species observed during sampling but not intercepting any line segment was recorded as an "incidental" species (one occurrence) in that site. Each wetland was sampled once in mid-growing season (July-August); the SRS sites were sampled in 1993 or 1995 and the regional sites in 1996. Vegetation was relatively stable over this 4-yr period (personal observations), given that cumulative rainfall was $3-5 \%$ above 30 -yr normals and there was no severe drought (National Oceanic and Atmospheric Administration 1993- 1996).

For each wetland, we calculated percent frequency of each species (i.e., percent of all line segments in which a species was present, irrespective of stratum) as a measure of species abundance. A very low value $(<0.5 \%)$ was assigned to incidental species. We used cluster analysis of the site-by-species 'abundance matrix to classify the individual wetlands into vegetation types objectively. Clustering was performed with PCORD software (McCune and Mefford 1995) using the UPGMA method (unweighted pair-groups, averagelinkage) with the Sorenson dissimilarity measure. Cluster analysis identified six distinct vegetation types and failed to classify only one of the 57 sites. Indicator Species Analysis (Dufrêne and Legendre 1997, in PCORD) was used to identify species that were strongly associated with particular wetland types. As a measure of vegetation vertical structure, the average percent of wetland sample units (line segments) with midstory and/or canopy strata was calculated for each wetland type.

\section{Wetland Environmental Variables}

We measured local (site-level) environmental variables for each wetland, including its size, hydrologic regime, soil properties, and disturbance history. Wetland size was measured as two-dimensional area estimated from digitized aerial and satellite images (Lide, unpublished data); area was highly correlated with wetland long-axis length measured in the field (Pearson $r=0.84, n=57, \mathrm{P}<0.001)$.

Wetland hydroperiod (seasonal ponding duration) was described with quantitative and qualitative mea- sures. For the SRS sites, hydrographs of weekly pond stage (water depth) during 1995 and 1996 (Lide and Sharitz, unpublished data) indicated that wetlands typically reached maximum depths by early April and drew down to the lowest levels by late November, an 8 -month period roughly corresponding to the regional growing season. For each year, we quantified each SRS wetland's growing-season hydroperiod as the coefficient of variation (CV) of mean monthly water depth over this $\mathrm{S}$-month period. CV is an inverse measure of hydroperiod length (i.e., a smaller $\mathrm{CV}$ indicates less seasonal fluctuation of water levels and a longer ponding duration). $\mathrm{CV}$ values $<0.6$ indicate permanent to semi-permanent ponding (duration 7-8 mo), values 1.5-1 .O indicate seasonal ponding (duration 3-6 mo), and values $>1.5$ indicate temporary ponding (duration $<3$ mo). Annual rainfall was $26 \%$ above average $(1506 \mathrm{~mm})$ in 1995 and $18 \%$ below average $(975 \mathrm{~mm})$ in 1996, allowing hydrology to be characterized during comparatively wetter and drier years. We used 1995 average pond stage to compare typical water depths of the wetland types.

For the regional wetlands, the available hydrologic data were pond-stage measurements from two to four site visits between July and December 1996. We constructed a qualitative index of hydroperiod by ordering the SRS wetlands according to 1996 mean water depth and then ranking them for ponding duration, where 4 = continuously ponded, 3 = drying down in late summer or early autumn (August-October), $2=$ dry by early summer (May-June) and not re-flooding until winter, and $1=$ mostly dry except for minimal early ponding (March-April). This index was validated by a high correlation with the $1996 \mathrm{CV}$ (Pearson $\mathrm{r}=$ $-0.96, n=34, \mathrm{P}<0.001)$. We then used the pond stage observations (plus information from landowners) to assign a score to each regional wetland. Higher index values indicate longer seasonal ponding duration.

We assessed physical and chemical soil properties of each wetland. Depending on wetland size, two to four soil profiles per wetland were described (noting horizons and textures to $152 \mathrm{~cm}$ depth) and assigned to soil series. Profiles were spaced along a transect spanning the wetland interior from the periphery to the center. In general, the soils were sandy with variable presence and depth of denser clay layers that might cause shallow ponding of water. We quantified soil textural type as mean thickness of the sandy "epipedon' ' over a clayey (i.e., clay or sandy clay texture) horizon. Each wetland's soil type was also classed as either "clayey" or "sandy" based on soil family (Soil Survey Staff 1975). Adjacent to the central profile in each wetland, composited soil samples were collected at O-1 $5 \mathrm{~cm}$ depth (topsoil) and at $61-76 \mathrm{~cm}$ depth (subsoil). Samples were analyzed for $\mathrm{pH}$, total percent 
$\mathrm{N}$, and total macronutrient concentrations $(\mathrm{P}, \mathrm{K}, \mathrm{Mg}$, Ca). Percent $\mathrm{N}$ was highly correlated with percent organic matter (Pearson $r=0.95$ and 0.59 for topsoil and subsoil, respectively, both $\mathrm{P}<0.01$ ). Chemistry differences between soil classes (clayey versus sandy) were tested by analysis of variance (ANOVA); all variables except $\mathrm{pH}$ were log-transformed for analysis.

We interpreted aerial photographs from the early 1950s (black-and-white 1:20,000 scale) to assess historic wetland alterations as well as land-use intensity in the adjacent uplands. Intensity of direct wetland impacts (ditching, clearing, row cropping, and grazing as suggested by fences) was scored with a disturbance index, where: $0=$ no evident disturbance, $1=$ minor impact such as a small ditch or track, $2=$ one major impact such as clearing or a large ditch, $3=$ two major impacts, $4=$ substantial intrusion of surrounding land use (such as clearing and row cropping) into the wetland interior. We also assigned scores for ditching impacts alone (indicating possible hydrologic alteration, either to drain out of or into the wetland), where $0=$ no apparent ditches, $1=$ small ditch at wetland periphery, 2 = one larger ditch, $3=$ two or more large ditches through the wetland interior. Adjacent land-use intensity was quantified as the percent of a 100-mwide upland zone around each wetland that was open agricultural land (versus sparsely treed or forested). The SRS wetlands incurred little new disturbance since $195 \mathrm{I}$; we examined later photography for the regional wetlands to note any subsequent major disturbances. With few exceptions, the regional wetlands showed no additional impacts since the early 1950s, and overall, they had disturbance scores equivalent to or lower than the SRS wetlands (ANOVA tests). This supported our assumption that the two site groups had comparable successional status and could be analyzed collectively.

Across the pre-settlement Coastal Plain, wildfire was an important natural disturbance process and likely affected both upland and wetland vegetation (Christensen 1988). However, fire suppression has been practiced across the study region for many decades, apart from some use of prescribed burns for forest management. On the SRS, where managed forests were burned periodically, fire spread into depression wetlands was usually minimized by cleared fire lanes or by burning at times of high water levels. As a general index of possible fire impact on the study sites, we assigned a score to each SRS wetland for the number of years since the last burn in the timber compartment where the wetland was located, where $1=$ O-3 yr, $2=4-7 \mathrm{yr}, 3=8-12 \mathrm{yr}$, and $4=>12 \mathrm{yr}$ (unpublished records of the US Forest Service-Savannah River). Regional wetlands were scored on the same scale based on information from the landowners.
Analysis of Vegetation-Environment Relationships

To determine which local environmental factors were related to plant composition, we analyzed the vegetation data by ordination (indirect gradient analysis) and then correlated the ordination scores (positions of sites along the important ordination axes) with the measured wetland variables. Ordination uses all the site-by-species data and provides more sensitive analyses than comparing a limited number of vegetation types (Peet 1980). The array of sites and species along the ordination axes (representing the similarities and differences among sites in their species composition) is interpreted as suggesting underlying environmental gradients as "seen" by the plants (McCune and Grace 2002). Based on various iterations, we found that vegetation-environment relationships were best resolved with a combination of a) Detrended Correspondence Analysis (DCA) and b) Non-metric Multi-Dimensional Scaling (NMDS) with dataset fragmentation (Peet 1980), a technique involving removal of distinctive site groups and re-ordination of the remaining sites. CANOCO software (ter Braak 1993) was used for DCA and PC-ORD for NMDS, with Bray-Curtis scores used as the input coordinates for NMDS. We used both methods because DCA provided better resolution of compositional variation across long $(>4$ s.d. units) first-axis gradients (ter Braak 1995), whereas NMDS gave clearer environmental correlations for fragmented data subsets.

Relationships between environmental variables and ordination scores on the most important axes were tested with Spearman rank correlations. We interpreted any correlation coefficient meeting a single-test significance criterion of $\mathrm{P}<0.05$ as suggesting a potential influence of the variable on vegetation. We then compared the significant variables among the classified wetland types to determine if some types had distinctive values of these local factors. Variables were tested by ANOVA because all were ordinal-scale or ratioscale data (Zar 1999) and there were no serious departures from assumptions. Arcsine square root transformations were used for percentage data and the square root transformation for CV data. Specified comparisons between wetland types were tested with multiple contrast (Scheffe) tests.

\section{Landscape Analyses}

To test whether plant composition (the site-by-species matrix) differed generally among landscape settings, we used multiple-response permutation procedures (MRPP), a non-parametric method for testing group differences in multivariate data (McCune and Mefford 1995). We also used a chi-square test to an- 
alyze whether wetland types were non-randomly distributed across the three landscapes. We used ANOVA to test whether the important local wetland variables differed between landscape settings. Finally, we used MRPP to test whether species composition generally differed (independent of landscape setting) between the SRS sites within a protected area of managed forests and the regional sites located across a wider area of more varied land uses (agriculture, fruit orchards, and managed forests).

\section{Temporal Vegetation Change}

The known history of the SRS wetlands provided a time frame for assessing longer-term vegetation dynamics. Before the SRS was established in 1950-51, farming was a major land use across the area. Many wetland depressions had been ditched, and some were used for crops or pasture whereas others appeared less disturbed (Kirkman et al. 1996). After 195 1, the farmed uplands and some agriculturally-altered wetlands were converted to pine forestry. However, other depressions were relatively intact or otherwise received little new disturbance, and abandonment plus natural infilling of ditches allowed some recovery of pre-disturbance hydrologies (Kirkman et al. 1996). Because apparent disturbance histories of SRS and regional sites were similar, the study wetlands collectively represented sites of minimally disturbed vegetation or nearly 50 years of post-disturbance succession.

We used a qualitative change-detection approach to describe long-term vegetation change (see also Kirkman et al. 1996). From stereo pairs of the historic (1950s) black-and-white aerial photos, we scored the dominant vegetative cover of each wetland interior as either open herbaceous ( $<25 \%$ of area wooded), sparsely-wooded $(25-70 \%$ wooded; possibly successional old fields or shrubby meadows), or forested ( $>70 \%$ wooded). We interpreted historic cover conservatively because photo resolution was not always sufficient to distinguish some herbaceous vegetation types (e.g., whether pasture or natural meadow) or different forest types. We then compared the historic cover types to current wetland vegetation type, with a focus on transitions from non-forest to forest cover. Overall significance of vegetation change was tested by chi-square. We synthesized the information on vegetation-environment relationships and long-term changes to develop a yualitative model that suggests possible wetland dynamics in response to key ecological processes in different environmental settings.

\section{RESULTS}

Wetland Vegetation Types

Upper Coastal Plain depressions support six broadly-defined wetland vegetation types (Figure 1, Table 2, and Appendix 1). Four types are principally herbaceous. "Open-water ponds" are characterized by water lily (Nymphaeu odoruta) and other aquatic macrophytes, with emergent plant species fringing the shallow wetland margins. Three emergent wetland types are distinguished by different dominant graminoid species: "grass marsh" by Panicum hemitomon (maidencane), "depression meadow" by Leersia hexandra (cutgrass), and "sedge marsh/meadow" by Carex striata (peatland sedge). These graminoid species are all clonal perennials that can form nearly continuous cover in a given wetland. Emergent wetlands also have diverse forb species in low abundances (typically, species of Ludwigia, Rhexia, and Polygonum); associated woody species fringe the wetland margins or may be scattered throughout. Of two forested wetland types (Table 2 and Appendix 1), "swamp forests" are dominated by the obligate (OBL) wetland trees Nyssa biflora (swamp tupelo) and/or Taxodium spp. (pond cypress, baldcypress), whereas "bottomland hardwoods" wetlands are characterized by facultative (FAC) trees such as Liquidamhar styraciflua and Acer rubrum (red maple) (indicator categories from Reed 1988). Ground-layer vegetation in closedcanopy forested wetlands is generally sparse, but facultative woody vines such as Campsis (trumpet creeper) and Smilax (catbriers) occur frequently in the bottomland hardwoods type.

Because wetland types differ in their species assemblages, a large number of species is found at a regionwide (landscape) scale. A cumulative total of -300 plant species was found across all 57 wetlands, but the number of species sampled in any single wetland averaged $22(\mathrm{SE}=1)$. Wetland vegetation types had similar average numbers of sampled species (Table 2; ANOVA, $\mathrm{F}=1.5, \mathrm{df}=5,50, \mathrm{P}>0.10$, not significant).

Vegetation-Environment Relationships

Ordination analyses confirmed that plant species composition differed widely among individual wetlands: DCA axis lengths approached or exceeded 4 s.d. (Table 3), which implies minimal or no similarity between sites at the axis extremes. There was little separation between the SRS and regional wetlands in the DCA ordination (Figure 2), which means that the two groups had a similar range of wetland types and species composition (MRPP test, $\mathrm{P}>0.10$, not significant). DCA Axis 1 represented the structural and com- 


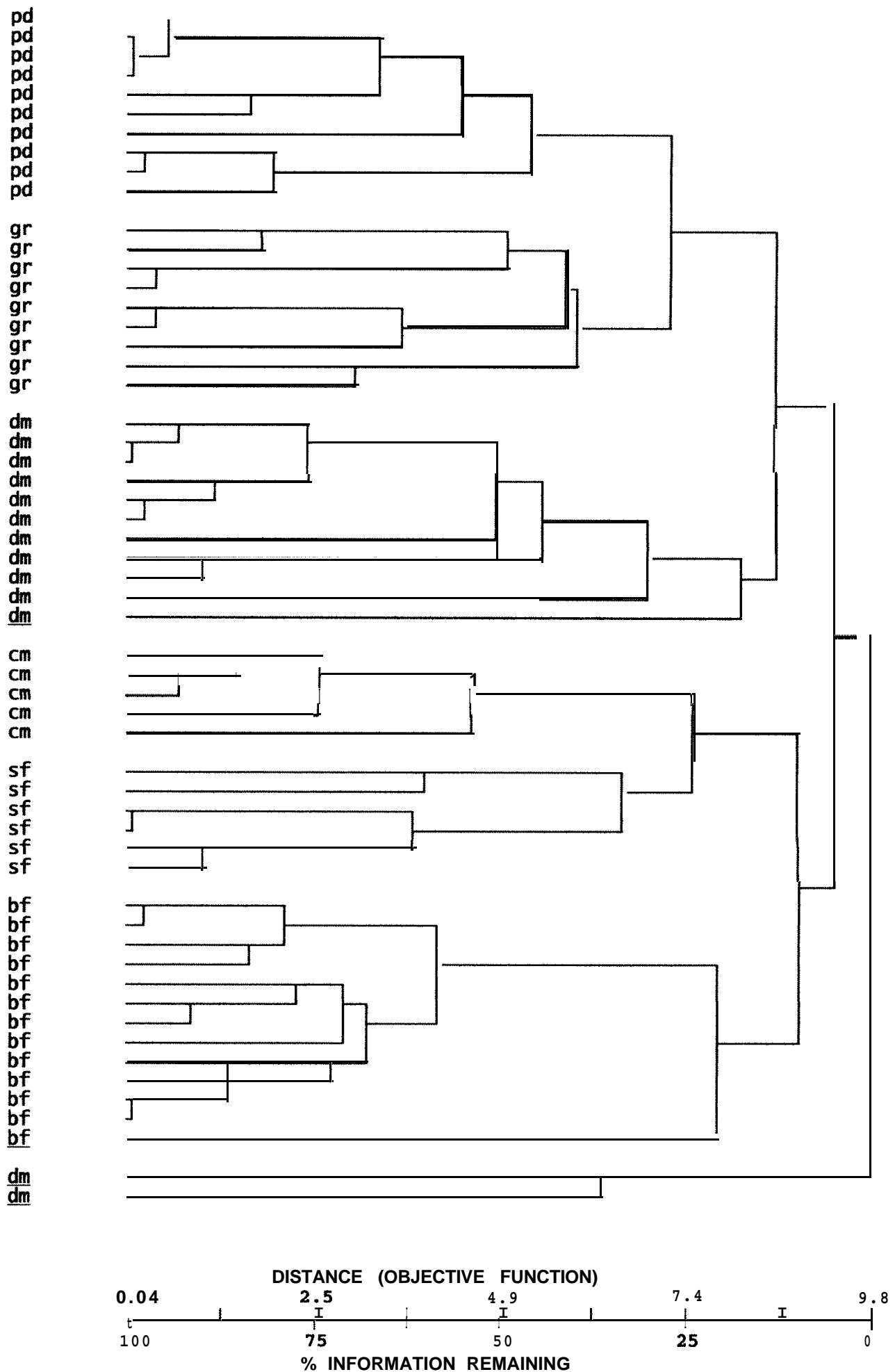

Figure 1. Upper Coastal Plain depression wetland types as classified by cluster analysis. "Distance (objective function)" indicates loss of similarity information as clustering proceeds. Each wetland site is represented by a symbol for vegetation type, where $\mathrm{pd}=$ open-water pond, gr = grass marsh, $\mathrm{dm}=$ depression meadow, $\mathrm{cm}=$ sedge marsh $/ \mathrm{meadow}, \mathrm{sf}=\mathrm{swamp}$ forest, and bf = bottomland hardwood forest. Underlined sites (outliers) were classed using supplemental ordination analyses, and one intermediate site that could not be classified is omitted. 
Table 2. Features of six depression wetland vegetation types. "Percent overstory" is the percentage of wetland sample units that had a canopy (overstory) stratum. Characteristic dominant species occur at high abundances in $\geq 90 \%$ of wetlands in the type; associated species occur at moderate abundances in $40-90 \%$ of wetlands in the type. Species abundance data are in Appendix 1.

\begin{tabular}{|c|c|c|c|c|c|}
\hline Wetland Type" & $n$ & $\begin{array}{l}\text { Species } \\
\text { Richness }\end{array}$ & $\begin{array}{c}\text { Percent } \\
\text { Overstory }^{b}\end{array}$ & $\begin{array}{l}\text { Characteristic } \\
\text { Dominant Species }\end{array}$ & Principal Associated species \\
\hline Open-water pond & 10 & $22(2)$ & $17(4)$ & Nymphaea odorata & $\begin{array}{l}\text { Eleocharis equisitoides, } P \text {. hemitomon, } \\
\text { Pontederia lanceolata, Brasenia schreberi }\end{array}$ \\
\hline Grass marsh & 9 & $21(3)$ & $30(7)$ & Panicum hemitomon & $\begin{array}{l}\text { Sphagnum spp., Cephalanthus occidentalis, } \\
\quad \text { Leersia hexandru, Nyssa biflora, Rhexia spp. }\end{array}$ \\
\hline Depression meadow & 13 & $20(3)$ & $7(2)$ & Leersia hexandra & $\begin{array}{l}\text { Eleocharis melanocarpa, E. acicularis, } \\
\text { Ludwigia sphaerocarpa, } P \text {. hemitomon, } \\
\text { Rhexiu spp. }\end{array}$ \\
\hline Sedge marsh/meadow & 5 & $32(7)^{\prime}$ & $40(11)$ & $\begin{array}{l}\text { Carex striata (syn. C. wal- } \\
\text { teriann) }\end{array}$ & $\begin{array}{l}\text { Nyssa biflora, Pontederia lanceolata, } \\
\text { Taxodium spp. }\end{array}$ \\
\hline Non-alluvial swamp forest & 6 & $18(3)$ & $79(10)$ & Nyssa biflora & Taxodium spp. (T. ascendans, T. distichum) \\
\hline $\begin{array}{l}\text { Non-alluvial bottomland } \\
\text { hardwoods forest }\end{array}$ & 13 & $22(2)$ & $81(5)$ & Liquidambar styraciflua & $\begin{array}{l}\text { Acer rubrum, Campsis radicuns, Nyssa } \\
\text { sylvatica, Smilax rotundifolia }\end{array}$ \\
\hline
\end{tabular}

a Names follow usage of other authors (Bennett and Nelson 1991, Whipple et al. 1981) where similar vegetation types were identified.

h Data are the mean (SE), where $\mathrm{n}$ is the number of wetlands classed into each type.

c Excluding an exceptional site with 58 species, mean species richness (SE) of sedge marsh wetlands was 26 (5).

Table 3. Ordination summary statistics and Spearman rank correlations between wetland environmental variables and ordination axis scores for wetland plant composition. For DCA, $n=57$ sites; for NMDS, $n=44$ sites (omitting 13 depression meadows). Ordering of sites on NMDS Axis 1 was similar to DCA Axis 1 . Correlations significant at $\mathrm{P} \leq 0.05$ are indicated by *.

\begin{tabular}{|c|c|c|c|}
\hline & DCA Axis 1 & DCA Axis 2 & NMDS Axis 1 \\
\hline DCA axis length in s.d. units" & 4.6 & 3.9 & \\
\hline Wetland area & $-0.31 ”$ & $-0.28 ”$ & $-0.38 ”$ \\
\hline CV of water depth, 199.5" & $0.46^{*}$ & $0.44^{*}$ & $0.60 ”$ \\
\hline Sandy epipedon thickness & $-0.34 ”$ & 0.09 & -0.22 \\
\hline Total N, topsoil & -0.21 & $-0.36 ”$ & $-0.41 ”$ \\
\hline Total P, topsoil & -0.10 & -0.09 & $-0.31 ”$ \\
\hline Total K, topsoil & -0.24 & 0.08 & -0.29 \\
\hline Total $\mathrm{Ca}$, topsoil & -0.14 & -0.09 & $-0.30 ”$ \\
\hline Total K, subsoil & -0.20 & 0.21 & -0.14 \\
\hline Total Ca, subsoil & -0.02 & 0.05 & -0.09 \\
\hline Total Mg, subsoil & 0.01 & -0.21 & -0.14 \\
\hline pH, subsoil & $-0.33 ”$ & 0.10 & -0.21 \\
\hline Index of historical disturbance & 0.19 & 0.24 & $0.37 ”$ \\
\hline Index of historical ditching & 0.25 & 0.11 & $0.31 ”$ \\
\hline Historical adjaceoptenland $(\%)$ & 0.25 & 0.21 & 0.27 \\
\hline Recency of burning score & 0.01 & -0.25 & -0.15 \\
\hline
\end{tabular}

is.d. = standard deviation.

b Data available only for SRS wetlands $(\mathrm{n}=35)$. 


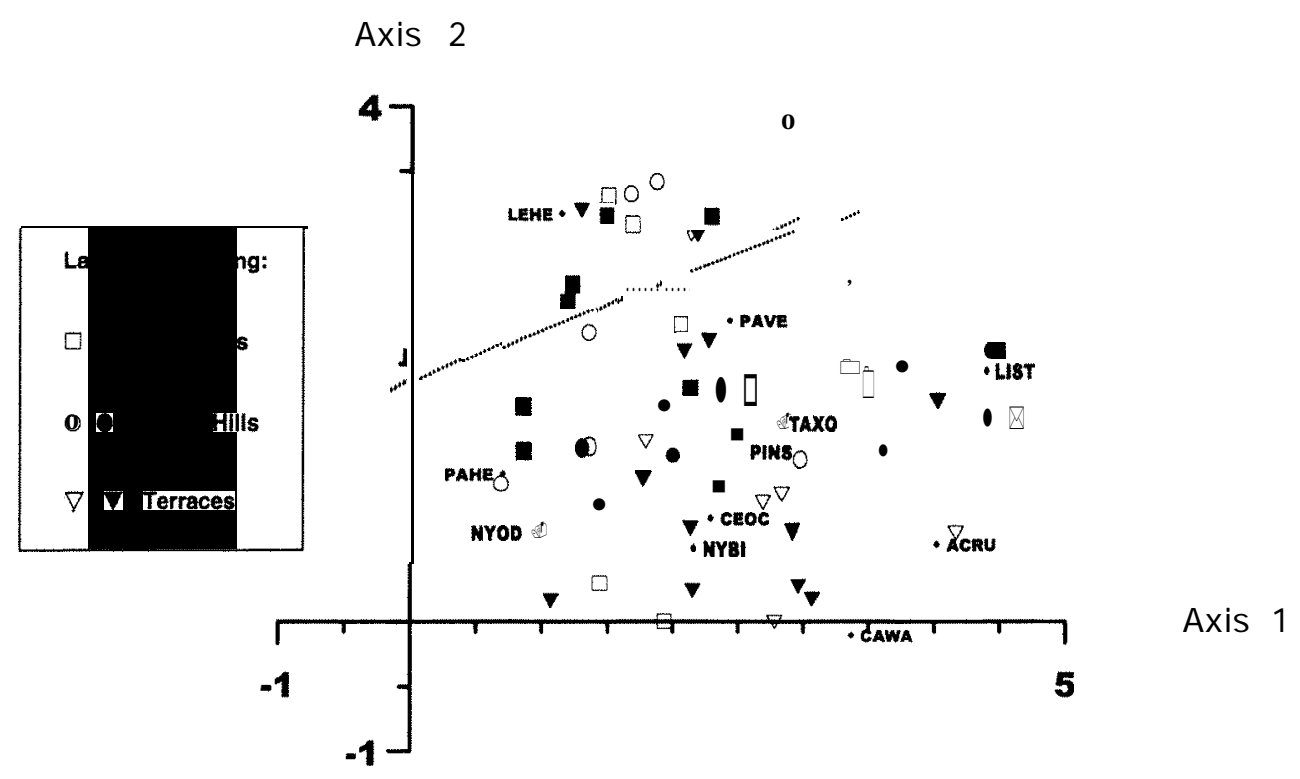

Figure 2. DCA ordination biplot showing relative similarities in plant composition among 57 depression wetlands. Filled symbols are SRS wetlands and open symbols are regional wetlands. Dotted line delineates 13 depression meadow wetlands omitted in NMDS ordination. Relative positions of the most important species are also shown. Species codes: ACRU $=$ Acer rubrum, $\mathrm{CAWA}=$ Carex striata, $\mathrm{CEOC}=$ Cephalanthus occidentalis, LEHE = Leersia hexandra, LIST $=$ Liquidambar styraciflua, NYOD = Nymphaea odorata, NYBI $=$ Nyssa biflora, PAHE = Panicum hemitomon, PAVE $=$ Panicum verncosum, PINS = Pinus spp., TAXO = Taxodium spp.

positional gradient from open-water ponds and emergent wetlands (low scores) to forested wetlands (high scores). Leersia depression meadows were compositionally distinct, as indicated by high scores on DCA Axis 2. When this group was omitted (data fragmentation), the NMDS ordination replicated the non-forest to forest gradient of DCA Axis 1 and helped to clarify some environmental correlations.

Of all local environmental factors, hydrology variables correlated most consistently with the ordination scores for wetland species composition (Table 3). Soil textural type (sandy epipedon thickness) was significant as well. Wetland soils were either clayey (Rembert, Coxville, and McColl series), shallow sands with typic profiles (Ogeechee series), or deeper sands with arenic and grossarenic profiles (Pelham, Williman, and Plummer series) (terminology follows U.S. soil taxonomy system, Soil Survey Staff 1975). Soil textural classes generally differed in nutrient chemistry, mainly in the subsoil, with clayey soils having lower $\mathrm{pH}$ and higher macronutrient concentrations than sandy soils (Appendix 2). However, most soil chemistry variables for individual wetlands were not directly correlated with the ordination scores (Table 3). The few significant elements (topsoil $\mathrm{N}, \mathrm{Ca}$, and $\mathrm{Mg}$ ) paralleled the hydrologic gradients; this possibly reflects greater organic matter accumulation (elevating $\mathrm{N}$ content and cation storage) in longer-hydroperiod wetlands. Wetland size and historic disturbance variables were also correlated with species composition (Table 3), but there was no detectable influence of prescribed fire in proximity to the wetlands (at compartment scale).

The significant local environmental variables differed between wetland types, although not always uniquely (Table 4). Open-water ponds were generally larger than other wetlands and were characterized by nearly continuous and deep ponding (mean water depth $=1 \mathrm{~m}$ ). Grass marsh, sedge marsh, and swamp forest had shallow ponding and relatively long growing-season hydroperiods, whereas bottomland hardwood forests had the shortest seasonal hydroperiods. Depression meadow hydroperiods appeared variably seasonal, with longer durations in the wetter year (1995) and much shorter durations in the drier year (1996). In the case of some wetland types (pond, grass marsh), individual sites could have either clayey or sandy soils. However, most depression meadows had sandy soils (nearly $70 \%$ of sites), whereas the forested wetland types generally occurred on clayey soils (85$100 \%$ of sites).

Bottomland hardwoods wetlands had the highest levels of' historic disturbance and adjacent agricultural land use (Table 4). In contrast, swamp forest wetlands had the lowest levels of past disturbance and adjacent land-use intensity. Paralleling this land-use difference, $>60 \%$ of swamp depressions historically had alluvial forested wetland within $100 \mathrm{~m}$ proximity, whereas $<10 \%$ of the bottomland hardwood depressions had 
Table 4. Variation in local environmental factors between depression wetland types. All data are means (SE) except "\% of wetlands with clayey soil". Variables are noted as significant $(*)$ at $\mathrm{P} \leq 0.05$ or $(\dagger)$ at $0.05<\mathrm{P} \leq 0.10$; all variables tested by ANOVA except "\% wetlands with clayey soil" (tested by chi-square). Contrasting high (boldface) or low (underlined) mean values of each variable are noted (Scheffe contrast tests). Number of wetlands for each type as in Table 2.

\begin{tabular}{|c|c|c|c|c|c|c|}
\hline \multirow[b]{2}{*}{ Variable } & \multicolumn{6}{|c|}{ Wetland Type } \\
\hline & $\begin{array}{l}\text { Open-Water } \\
\text { Pond }\end{array}$ & $\begin{array}{l}\text { Grass } \\
\text { Marsh }\end{array}$ & $\begin{array}{r}\text { Depression } \\
\text { Meadow }\end{array}$ & $\begin{array}{c}\text { Sedge } \\
\text { Marsh/Meadow }\end{array}$ & $\begin{array}{l}\text { Swamp } \\
\text { Forest }\end{array}$ & $\begin{array}{l}\text { Bottomland } \\
\text { Forest }\end{array}$ \\
\hline Mean seasonal water depth $(\mathrm{m})^{*}$ & $1.5(0.2)$ & $0.5(0.1)$ & $0.5(0.1)$ & $\mathbf{0 . 6}(0.1)$ & $0.5 \quad(0.02)$ & $0.3(0.1)$ \\
\hline CV of water depth", 1995* & $0.1(0.02)$ & $\mathbf{0 . 4}(0.1)$ & $0.4 \quad(0.2)$ & $0.1(\mathbf{0 . 0 4 )}$ & $0.2 \quad(0.04)$ & $1.0(0.2)$ \\
\hline CV of water deptha, $1996^{*}$ & $\overline{0.2}(0.1)$ & $1.1 \quad(0.3)$ & $1.3(0.4)$ & $\underline{0.3}(0.1)$ & $0.9 \quad(0.7)$ & $1.7 \quad(0.3)$ \\
\hline Hydroperiod Index, 1996* & $\overline{3.8}(0.1)$ & $3.0 \quad(0.3)$ & $\underline{2.5}(0.3)$ & $2.9(0.6)$ & $3.2(0.5)$ & $\underline{2.2}(0.2)$ \\
\hline Sandy epipedon thickness $(\mathrm{cm}) \dagger$ & $69 \quad(16)$ & 62 (IS) & $89(14)$ & 71 (16) & $29(4)$ & $\overline{41}(6)$ \\
\hline$\%$ of wetlands with clayey" soil type" & 60 & 67 & 31 & 40 & 100 & 85 \\
\hline Wetland area (ha) $\dagger$ & $7(2)$ & $4(1)$ & $3(1)$ & $4(1)$ & $3(1)$ & $3(1)$ \\
\hline Index of historic disturbance* & $1.3(0.4)$ & $2.2(0.4)$ & $2.5(0.4)$ & $1.8(0.6)$ & $0.5 \quad(0.3)$ & $3.1 \quad(0.4)$ \\
\hline Index of historic ditching* & $1.0(0.3)$ & $1.6(0.2)$ & $1.0(\mathbf{0 . 3 )}$ & $1.2(0.5)$ & $\overline{0.5}(0.3)$ & $1.9 \quad(0.3)$ \\
\hline Historic adjacent open land $(\%)^{*}$ & $74 \quad(10)$ & $75 \quad(14)$ & $72(10)$ & 90 (6) & $43(12)$ & $96(2)$ \\
\hline
\end{tabular}

" Data for SRS wetlands only.

b Versus sandy soil type.

any other forested wetland nearby. While the incidence of past ditching was greatest in present-day bottomland hardwoods wetlands (Table 4), evidence of former ditching occurred in some sites of all wetland types, although most ditches now appear ineffective.

\section{Landscape-Level Patterns}

Species composition of individual wetlands differed among landscapes (Figure 2; MRPP test, $\mathrm{P}<0.001$ ). Similarly, the six wetland types were non-randomly distributed across landscape settings $\left(\chi^{2}=24\right.$. 1 , df $=$ $10, \mathrm{P}<0.01)$. Most Leersia depression meadows were found either within (54\%) or indirectly associated with (23\%) Sandhills landscapes, where deep sandy soils are common. All sedge marsh wetlands were found on lower-lying Terraces, whereas $77 \%$ of bottomland hardwoods wetlands were associated with the more intensively-used Loam Hills landscape. Ponds, grass marshes, and swamp forests occurred in all three landscapes with no apparent preference.

Local wetland factors important for vegetation could be predicted, at least partially, from the landscape setting (Table 5). Wetland soil textural type (sandy epipedon thickness) differed significantly between landscapes and reflected the predominant upland soil types

Table 5. Variation in local environmental factors between landscape settings. Values are means (SE) except "\% wetlands with clayey soil". ANOVA tests of differences among landscapes are noted as significant $\left(^{*}\right)$ at $\mathrm{P} \leq 0.05$, ( $\dagger$ ) at $\mathrm{P}<0.10$, or not significant (n.s.) ("\% wetlands with clayey soil" was tested by chi-square). Means sharing the same letter superscript (c, d) did not differ significantly in Tukey pairwise comparison tests.

\begin{tabular}{|c|c|c|c|c|}
\hline \multirow[b]{2}{*}{ Variable } & \multicolumn{3}{|c|}{ Landscape Setting } & \multirow{2}{*}{$\begin{array}{c}\text { Significance } \\
\text { of Landscape } \\
\text { Differences }\end{array}$} \\
\hline & Sandhills & Loam Hills & Terraces & \\
\hline Wetland area (ha) & $4.2(0.7)^{\mathrm{cdd}}$ & $5.1 \quad(1.0)^{\prime}$ & $2.5(0.4)^{\prime}$ & \\
\hline CV of water depth, $1995^{\prime}$ & $\mathbf{0 . 3}(0.1)$ & $0.9(0.2)^{d}$ & $\mathbf{0 . 3}(0.1)^{\prime}$ & \\
\hline CV of water depth, 1996' & $1.3(0.3)$ & $1.4(0.3)$ & $0.7 \quad(0.2)$ & n.s. \\
\hline Hydroperiod Index, 1996 & $2 . x \quad(0.3)$ & $2.8 \quad(0.2)$ & 3. $0(0.2)$ & n.s. \\
\hline Surface sand thickness $(\mathrm{cm})$ & 81 (12)' & $44(8)^{d}$ & $65(9)^{c}$ & \\
\hline$\%$ of wetlands with clayey soil type" & 41 & 82 & 56 & $*$ \\
\hline Index of historic disturbance & $1.4 \quad(0.3)$ & $2.7(0.3)^{d}$ & $2.2(0.3)^{\mathrm{c} d}$ & * \\
\hline Index of historic ditching & $0.9(0.2)^{\mathrm{c}}$ & $2.0(0.2)^{\mathrm{d}}$ & $1.2 \quad(0.2)$ & $*$ \\
\hline Historic adjacent open land $(\%)$ & so $(9)^{\prime}$ & 92 (4)" & $81(6)^{c, d}$ & $*$ \\
\hline Recency of nearby fire & $2.3(0.3)^{\mathrm{c}}$ & $3.3(0.2)^{d}$ & $3.2(0.3) "$ & $*$ \\
\hline Number of wetlands & 17 & 22 & 18 & \\
\hline
\end{tabular}

a Data for SRS wetlands only

h Versus sandy soil type. 
Table 6. Transitions between historic vegetation cover and current wetland vegetation types. Cell values arc number of wetlands in each transition category. Overall chi-square $=13.0, \mathrm{df}=5, \mathrm{P}<0.05$. Mean "\% canopy/midstory" (percent of sample units with canopy and/ or mid-story strata in each wetland) is noted below each current wetland type.

\begin{tabular}{|c|c|c|c|c|c|c|c|}
\hline $\begin{array}{c}\text { Historic Vegetation } \\
\text { Cover }\end{array}$ & \multicolumn{6}{|c|}{ Current Wetland Type } & $\begin{array}{c}\text { Row Totals } \\
(\%)\end{array}$ \\
\hline Open (non-forested) & 8 & 6 & 13 & 2 & 2 & 10 & $41(73)$ \\
\hline $\begin{array}{l}\text { Sparsely-wooded } \\
\text { Forested }\end{array}$ & $\begin{array}{l}0 \\
2 \\
\end{array}$ & $\begin{array}{l}3 \\
0\end{array}$ & $\begin{array}{l}0 \\
0\end{array}$ & $\begin{array}{l}3 \\
0\end{array}$ & $\begin{array}{l}0 \\
4\end{array}$ & $\begin{array}{l}2 \\
1\end{array}$ & $\begin{array}{l}8(14) \\
7(13)\end{array}$ \\
\hline \% canopy/midstory & 18 & 43 & 1.5 & 43 & 79 & 87 & \\
\hline
\end{tabular}

a Omits one intermediate site that could not be classified to a vegetation type

of each setting. In the Sandhills uplands, $59 \%$ of wetland sites had sandy soils, compared to $44 \%$ of Terrace wetlands and $18 \%$ of sites in the Loam Hills $\left(\chi^{2}=\right.$ 7.1 , df $=2, \mathrm{P}<0.05)$. Data from the SRS sites suggested that wetland hydroperiods tended to be longer (smaller CVs) in Terrace landscapes and shorter (larger $\mathrm{CVs}$ ) in Loam Hills landscapes, whereas hydroperiods of Sandhills wetlands varied more between years (Table 5). Overall, hydroperiods did not differ between wetland soil classes (clayey or sandy), but there was an interaction effect between soil class and landscape setting. In the Loam Hills setting only, wetlands with clayey soils had shorter hydroperiods than wetlands with sandy soils (ANOVA, F = 5.0, df $=1,20, \mathrm{P}<$ 0.05 ). Wetlands in the Loam Hills had generally higher values for the historic disturbance indices (Table 5). Sandhills landscapes had experienced more recent fires from prescribed burning, but it is unknown if these fires had any direct impacts on wetland vegetation.

\section{Vegetation Dynamics}

Change-detection analysis suggested relatively stable vegetation in some wetlands and succession in others. In the early 1950s, most wetland sites were either non-forested or sparsely-wooded (Table 6, row totals $=87 \%$ ); currently, $85 \%$ of these historically open sites (35 of 49) still have herbaceous vegetation types (pond, marsh, meadow). All present-day depression meadows were also open habitats historically, as were most grass and sedge marshes. Of the few wetlands that were forested historically (Table 6, row total = $13 \%$ ), most are still forested (generally as swamp forest) or have transitioned to open-water ponds because of recent enhanced flooding. However, of the wetlands currently in bottomland hardwoods forest, nearly all were historically open or sparsely-wooded, indicating succession to closed forest since abandonment.

Shared species composition among present-day wet- land types (Table 2, Appendix 1) also suggests possible directions of vegetation change in response to changing hydroperiods. Grass marshes were transitional in composition, and thus potentially successional, between open-water ponds and swamp forests. Sedge marshes share composition with swamp forest in having cypress and/or swamp tupelo as associated species. Compared to other emergent wetland types, trees were more minor components of depression meadows, but in some meadow sites, we observed zones of dead pine saplings around the wetland peripheries. The pines had colonized during a drought period in the late 1980s but then died back after subsequent reflooding in the early 1990s (see also Kirkman 1995).

\section{DISCUSSION}

Local Factors and Wetland Vegetation

The vegetation of Upper Coastal Plain depressions is diverse at the landscape scale, with at least six wetland types distributed throughout the region. The vegetation types derived from our quantitative data are similar to types suggested by earlier qualitative surveys (e.g., Bennett and Nelson 1991), which suggests fairly predictable groupings of plant composition. An even broader scale of analysis will be needed for a comprehensive understanding of Coastal Plain depressions because additional vegetation communities such as shrub pocosin and cypress savanna occur mainly in the Middle and Lower Coastal Plain regions (Weakley and Schafale 1990, Bennett and Nelson 1991, Nifong 1998).

With respect to our first question, wetland vegetation is influenced by local environmental gradients, although in complex ways. Hydrologic regime was the strongest correlate of vegetation type. Depression size interacted with hydrology to favor open-water pond vegetation in large, deep basins with very long hydro- 
periods; however, size was otherwise not strongly related to vegetation type (although possibly smaller wetlands tend to be forested). Forested wetlands generally occurred on clayey soils, whereas the depression meadow type typically had deep sandy soils. Other vegetation types showed no specific relation to soil type.

Depressional wetlands are regarded as primarily precipitation-driven, but connections to the water table may stabilize and lengthen hydroperiods. Multiple interacting factors likely influence a particular wetland's hydrologic regime, including basin size (water storage volume) and relative elevation and relief (potential for ground-water inputs) (Lide et al. 1995, Chmielewski 1996). Our preliminary analyses suggested four possible hydrologic patterns that could be used to characterize a depression wetland: 1) semi-permanent and deep ponding, 2) long-seasonal and shallow ponding, 3) shallow ponding with variable duration in wetter and drier years, and 4) short seasonal ponding duration in most years. Individual depressions have different characteristic patterns during "normal" climatic conditions, but during prolonged drought cycles, the differences are diminished and all wetlands may become dry (Kirkman 1995, De Steven, pers. observ.). Conversely, extremely wet years may also lessen amongwetland differences in hydroperiod length.

How different soil types specifically influence vegetation composition is unclear, but possible mechanisms include effects on hydrology, relative soil moisture retention during water drawdowns, and site fertility. Soils with shallow, dense clay horizons may cause water ponding that is perched above the ground-water table, resulting in smaller storage volumes and shorter seasonal hydroperiods than in wetlands with deeper sands that permit shallow ground-water connections (Hendricks and Goodwin 1952, Chmielewski 1996, Kirkman et al. 2000). Compared to clayey soils, lower nutrient content and droughtiness of sandy soils may limit fertility for plant growth, especially during water drawdowns.

Historically, many of these sites had been ditched for drainage and may have been cropped or pastured, but they have recovered to become functional wetlands. However, legacies of historical land uses may persist (Kirkman et al. 1996). Of all wetland types, the bottomland hardwoods forest was associated with the most intense historic disturbance. Dominated by facultative (FAC) tree species and woody vines, this wetland community appears to be a "regrowth" forest following prior wetland alteration (Bennett and Nelson 1991).

\section{Local Factors and Landscape Settings}

There is growing recognition that a landscape perspective is needed for understanding wetland diversity because hydrogeologic settings influence wetland properties (Bedford 1996, Gwin et al. 1999). For example, in Gulf Coastal Plain depression wetlands, Kirkman et al. (2000) demonstrated correlations between landscape position, hydroperiods, soils, and vegetation types. With respect to our second question, we found that landscape setting is a partial predictor of important local wetland variables, including depression soil type, size, and hydrology. Low-elevation Terrace landscapes have soils with properties that reflect slow drainage, high water tables, and ground-water influence. Depressions on the higher interfluvial ridges of the Loam Hills frequently have clayey soils with perched hydrologies that are more prone to seasonal drying. Depressions in the Sandhills landscape are more likely to have deep sandy soils. Potential landscape differences extend to disturbance regimes and land uses as well. As noted earlier, the more fertile Loam Hills uplands have experienced greater agricultural impacts (Myers et al. 1986), thus resulting in greater historic disturbance to wetlands in that landscape setting. Fire potential may also vary, with the xeric Sandhills uplands perhaps most fire-prone and the Terrace landscape the least so.

Landscapes are organized hierarchically because higher levels (e.g., climate, geological landform) constrain lower levels (e.g., topography, soil physical properties, vegetation) (Palik et al. 2000). Although we found a landscape framework to be important for understanding the distribution of depression wetland vegetation types, the properties of an individual depression were not entirely predictable from the landscape setting. Except for sedge marshes, no wetland type was uniquely restricted to a single landscape setting, but a few types had positive associations with particular settings. Therefore, wetland plant community development reflects "contingencies" of local factors and landscape contexts (Pickett and Parker 1994). Each landscape setting can potentially support a mosaic of depression vegetation types, often adjacent to each other, as a result of complex interactions determined by local site conditions and landscape-influenced historical legacies (Kirkman et al. 1996). These interactions can be summarized in a matrix of environmental "templates" for depression wetland types (Table 7), where the descriptive (tilled) cells indicate known or potential site conditions that favor particular vegetation communities. The "empty" cells illustrate that vegetation types are not necessarily constrained by a unique set of conditions, since some factors can override others (e.g., large deeply-flooded basins will likely support aquatic communities irrespective of soil type or landscape setting). 
Table 7. Environmental templates for Upper Coastal Plain depression wetland types. Cells indicate identified associations between vegetation type and environmental or landscape features; tentative associations are indicated by?, and empty cells ( $\longrightarrow$ ) indicate no association.

\begin{tabular}{|c|c|c|c|c|c|c|}
\hline \multirow[b]{2}{*}{ Wetland variable } & \multicolumn{6}{|c|}{ WETLAND TYPE } \\
\hline & $\begin{array}{l}\text { OPEN-WATER } \\
\text { POND }\end{array}$ & $\begin{array}{l}\text { GRASS } \\
\text { MARSH }\end{array}$ & $\begin{array}{l}\text { DEPRESSION } \\
\text { MEADOW }\end{array}$ & $\begin{array}{c}\text { SEDGE } \\
\text { MARSH/MEADOW }\end{array}$ & $\begin{array}{l}\text { SWAMP } \\
\text { FOREST }\end{array}$ & $\begin{array}{c}\text { BOTTOMLAND } \\
\text { HARDWOODS } \\
\text { FOREST }\end{array}$ \\
\hline $\begin{array}{l}\text { Ponding depth and } \\
\text { duration }\end{array}$ & $\begin{array}{c}\text { deep, } \\
\text { semi-permanent }\end{array}$ & $\begin{array}{l}\text { shallow, } \\
\text { long- } \\
\text { seasonal }\end{array}$ & $\begin{array}{l}\text { shallow, } \\
\text { variable }\end{array}$ & $\begin{array}{c}\text { shallow, } \\
\text { long-seasonal? }\end{array}$ & $\begin{array}{l}\text { shallow, } \\
\text { long-seasonal }\end{array}$ & $\begin{array}{l}\text { very shallow, } \\
\text { short-seasonal }\end{array}$ \\
\hline Soil type & variable & variable & sandy & (sandy?) & clayey & clayey \\
\hline Basin size & large & & & & (smaller?) & (smaller?) \\
\hline Past disturbance & & & & & lower & higher \\
\hline $\begin{array}{l}\text { Relative topographic } \\
\text { position }\end{array}$ & & & & lower & & higher \\
\hline Landscape setting & & & Sandhills & Terraces & & Loam Hills \\
\hline
\end{tabular}

\section{Vegetation Dynamics}

Across the southeastern Coastal Plain, two potential drivers of wetland vegetation dynamics are hydrologic variation and fire (Christensen 1988). For depressions, key hydrologic aspects are hydroperiod and water depth. Semi-permanent ponding occurs in large and deep basins, but smaller and shallower depressions can have a variety of hydroperiods. To different extents, water levels fluctuate seasonally in all depressions, particularly at the shallower margins, and most or all wetlands may dry down completely during prolonged droughts. Water drawdowns promote recruitment from dormant seed banks and may allow less flood-tolerant species, particularly woody plants, to colonize wetland interiors (Kirkman 1995, Collins and Battaglia 2001). When dry, wetlands are also susceptible to fire spread, which can kill fire-sensitive woody species. Artificial drainage shortens or removes wetland hydrology, thus permitting upland species to colonize as well.

With respect to our third question, the analyses of environmental factors and long-term vegetation change suggested a qualitative model that predicts how local factors and landscape settings may affect wetland dynamics in response to hydrologic changes and fire (Figure 3). Irrespective of soil type or landscape setting, large deeply-flooded depressions will support open-water ponds with aquatic macrophytes and with emergent plant species at the shallower wetland margins. In shallowly-flooded basins with long seasonal hydroperiods, emergent wetland types (marsh, meadow) can predominate. With increased seasonality or as hydroperiods are shortened by drought or altered drainage, woody plants can potentially establish. Two contrasting patterns of change may occur, depending in part upon wetland soil type and landscape setting. In the sandy depressions of the xeric and infertile Sandhills landscape, wetlands dominated by the Leersia depression meadow community appear to demonstrate a cyclic succession (Figure 3, top half of flow diagram), wherein drawdowns promote colonization by flood-intolerant pines that are killed following reflooding (Kirkman 1995). Depending upon their seasonal timing, fires could also inhibit pine establishment and maintain herbaceous meadow vegetation, particularly in the xeric landscapes that historically supported fire-dependent longleaf pine forests (Jones et al. 1984). Drainage would disrupt the cyclic pattern and permit succession to forest.

Alternatively, directional succession towards forested types (Figure 3, bottom half of flow diagram) may occur in more mesic landscape settings, where depressions often have finer-textured soils and where mixed 
LANDSCAPE SETTING

WETLAND SOIL TYPE
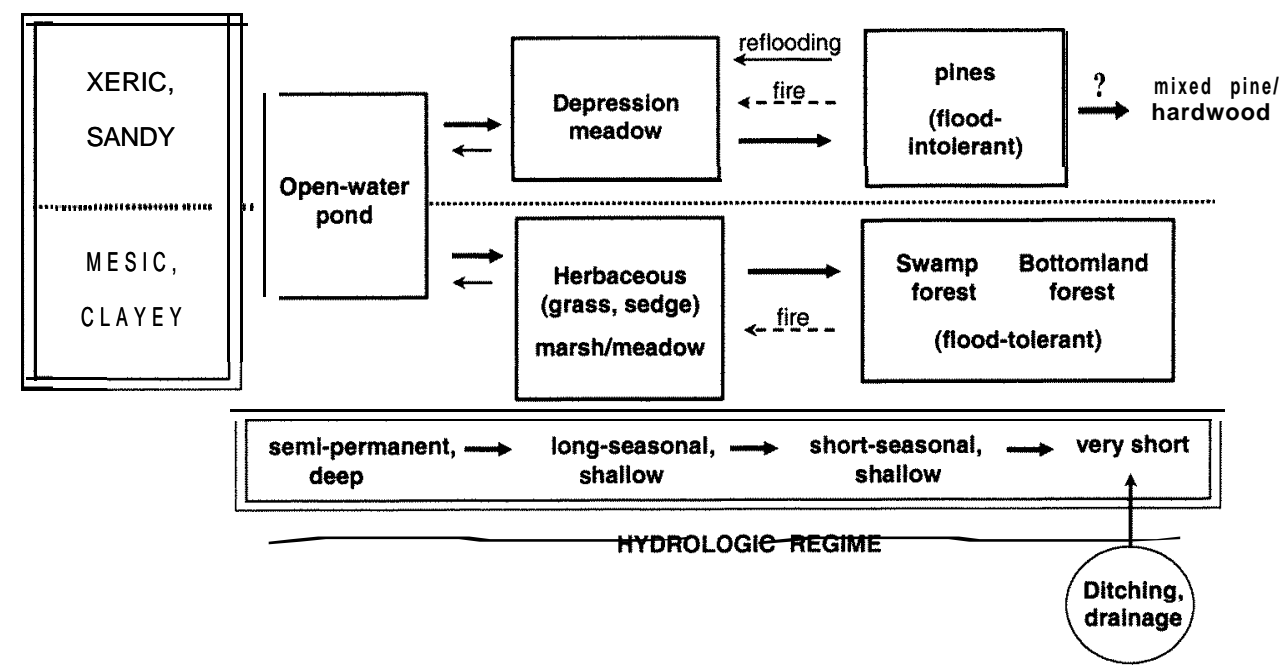

Figure 3. Model of potential vegetation dynamics in Upper Coastal Plain depression wetlands. Thick arrows indicate transitions promoted by shortened hydroperiods and shallower ponding depths; reverse arrows are predicted effects of reflooding (solid) or fire (dashed). Alternative pathways are suggested for xeric landscapes and sandy wetland soils versus mesic landscapes and clayey wetland soils.

hardwood-pine forests surround the wetlands. Shallow ponding depths and long hydroperiods would allow vegetative expansion of emergent vegetation (especially grass or sedge marsh), but shorter seasonal hydroperiods would permit both pines and flood-tolerant hardwood species to establish. Whether facultative (sweetgum, red maple) or obligate (swamp tupelo, cypress) hardwoods colonize will depend in part on the forest composition of the adjacent uplands and the proximity of other forested wetlands. Deep re-flooding might cause mortality of the most flooding-sensitive species but may not eliminate more flood-tolerant hardwoods. Over time, these trees could accelerate seasonal drying by their large transpiration demands (Sun et al. 200 1) and further promote forest development. Depending upon fire intensity and frequency, fire spread during drawdowns might retard forest succession or have only selective effects; for example, cypress may be more fire-resistant than swamp tupelo or the facultative hardwoods (Ewe1 199X) and thus be able to persist once established.

Our wetland model has parallels in the forest dynamics of Coastal Plain uplands, where soils and topographic setting influence succession toward xcric pine-oak forests on deep sandy soils or toward mesic hardwood-pine forests on finer-textured soils (Jones et al. 1984). In shallow Gulf Coastal Plain depressions, Kirkman et al. (2000) also related the dynamics of three wetland types (herbaceous meadow, cypress savanna, and cypress-gum swamp) to influences of soil type, ponding regime, and fire. Their model illustrates the potential interactions between hydroperiod and fire. For example, if relatively longer inundation excludes fire, then cypress-gum swamp is favored; alternatively, if shorter inundation allows more frequent fire, then herbaceous meadow results. In its basic processes, our model (Figure 3) is similar to theirs in suggesting that both greater inundation and increased tire frequency can inhibit flood-intolerant woody plants and promote herbaceous vegetation. We structured our model to illustrate that successional pathways may vary in relation to how the driving processes act in different landscape settings. The model also reflects the wider variety of vegetation types (including deeply-flooded ponds) in Upper Coastal Plain depressions, which generally appear to be more strongly driven by hydrologic regime than by fire at the present time.

In the forested landscapes of the southeastern United States, the significant role of woody plants in wetland dynamics contrasts with a well-established succession model for prairie pothole wetlands in the northern Great Plains region (van der Valk and Davis 197X), where drought-influenced vegetation cycles largely involve shifts in dominance among herbaceous vegetation types. Regionally-based models of vegetation dynamics are important for predicting the potential implications of future climate change on depression wetland systems. For example, under a scenario where droughts increase in frequency or sever- 
ity, more wetland hydroperiods could shift to shorter seasonality than at present, which would alter the regional distribution of different wetland types. In the prairie pothole region, a possible result of this scenario would be closure of open-water wetlands by emergent vegetation and loss of temporary or seasonal wetlands (Poiani and Johnson 1991). In the Southeast, the result could be more forested depressions and fewer herbaceous depressions, although the potential for more fires might be a counteracting force. We still need greater understanding of how interactions among driving variables might influence wetland responses to climate change.

\section{Applications}

Coastal Plain landscapes have experienced several centuries of impact from European settlement (Christensen 1988), and it is likely that few of the embedded depression wetlands remained completely undisturbed through their history. However, despite past disturbances, many depressions currently have functional hydrologic regimes and support diverse wetland vegetation and fauna. The plant communities now found in intact or recovered sites probably represent the best examples of least degraded "reference" vegetation for Upper Coastal Plain depressions. Thus, the vegetation classification, environmental templates, and dynamics model together can provide a regional reference framework for conservation, restoration, and management applications. Vegetation type, either directly or as reflecting different hydroperiods and substrates, may influence faunal assemblages (e.g., Pechmann et al. 1989, Snodgrass et al. 2000). Therefore, conservation of region-wide biological diversity would be promoted by protecting depressions with a variety of vegetation types across different landscape settings (Gwin et al. 1999). Knowledge of the landscape distribution of wetland types can aid protection efforts. For example, the depression-meadow vegetation type is relatively uncommon and also supports many rare plant species (Bennett and Nelson 1991); if such wetlands are a particular conservation priority, then a search for the best remaining examples for protection might be focused within Sandhills-type landscapes. Similarly, Terrace landscapes could be targeted to locate Carex marsh/ meadow depressions, which are relatively species-rich and uncommon on the Upper Coastal Plain.

The dynamic nature of Coastal Plain depressions presents complex challenges for their restoration and management. Because a common historic disturbance to these wetlands was drainage by ditching, re-establishing the pre-disturbance hydrologic regime by plugging or filling ditches may be key to initiating recovery processes. This approach has been used for drained prairie pothole wetlands (Galatowitsch and van der Valk 1996). To date, there has been little systematic research on methods to restore highly-altered Coastal Plain depressions (e.g., Singer 2001), but a regional reference system can provide some guidelines. For Upper Coastal Plain depressions, the vegetation classification identifies an array of possible objectives for restored plant communities, with quantitative reference data (Appendix 1) that describe the typical species composition of different wetland types (see also Kirkman et al. 2000). The environmental templates are a "model" for matching the desired plant community with favorable site conditions, within constraints implied by the dynamics model. For example, large deep basins should favor aquatic communities if a suitable flooding regime can be restored. Depression-meadow communities may be a feasible restoration objective in sites with deep sandy soils, but they could be harder to maintain on clayey soils that favor forest development, unless sites are managed (with greater cost and effort) by repeated prescribed burning or timber harvest. For shallow clayey depressions, swamp or bottomland forest may be a natural trajectory that would require minimal management effort once established. Fire can be used to maintain herbaceous vegetation types, but in urbanizing landscapes, there will be increasing constraints on the use of prescribed burning as a management tool, which may argue for more easily-maintained forested wetlands. However, this could result in lost habitat for rare flora or fauna that may require herbaceous wetlands.

In all cases, restoring depression wetlands by reestablishing hydrology will be successful only if desired species are in the seedbank and/or appropriate seed sources are nearby ("efficient community" model; Galatowitsch and van der Valk 1996). Otherwise, more expensive artificial seeding or planting measures may be needed to accelerate the recovery process. The nature of the surrounding uplands could also affect restoration outcomes. If restored wetlands are surrounded by agriculture, there may be few sources of suitable wetland species. If restored sites are within forested settings, the species of woody plants (pines or hardwoods) that may colonize the wetlands will depend upon the composition of the adjacent forest and how it is managed. The effects of upland forest management on wetland vegetation are relatively unexplored (e.g., Poiani and Dixon 1995, Kirkman et al. 1998).

Apart from some rapidly urbanizing areas, the Southeastern Coastal Plain is currently a mixed forested and agricultural landscape (Wear and Greis 2002). Therefore, our study encompassed the common settings where depression wetlands are located and where conservation or restoration will likely occur. Al- 
though many of our regional wetlands were in agricultural settings, these regional sites had comparable vegetation types and species composition to the SRS wetlands surrounded by forests (Figure 2). There may be more subtle differences in plant composition that we could not detect. However, at least for vegetation, our findings suggest that diverse depression wetlands can survive within various non-urban landscapes if disturbance to wetland interiors is minimized or discontinued to allow recovery. How Coastal Plain depressions may be impacted within highly degraded agricultural or urbanized landscapes is an area for further study. Some methods to develop indices of wetland condition (e.g., IBI, index of biotic integrity) attempt to predict current disturbance from land use variables, but this may be problematic because impacts to wetlands tend to occur locally rather than at a watershed or landscape scale (see Wilcox et al. 2002, Tangen et al. 2003). Where anthropogenic land use is not extremely intensive, it may predict the likelihood that wetlands will be disturbed or altered, rather than the condition of particular wetlands.

\section{ACKNOWLEDGMENTS}

The aid of many people made this study possible. We especially thank R.R. Sharitz of the Savannah River Ecology Laboratory (SREL) for facility and personnel support, R. Eppinette of the Natural Resource Conservation Service (NRCS) for the soil profile descriptions, and R. Lide (SREL) for hydrology data. For help with logistics, field work, or other advice, we thank B. Adams, L. Battaglia, S. Bennett, A. Edwards, M. Ford, A. Garris, C. King, S. Miller, J. Nelson, A. Pittman, V. Rogers, R. Scharf, J. Singer, D. Soblo, B. Taylor, C. Trettin, M. Vaitkus, G. Wein, and staffs of the U.S. Forest Service-Savannah River, SREL, and NRCS field offices in Allendale and Bamberg Counties, SC. Supplemental plant data were generously provided by G. Guntenspergen, J. Keough, and J. Grace (U.S. Geological Survey). Much of the research was conducted when the senior and junior authors were Associate Professor and Postdoctoral Associate, respectively, at the University of Wisconsin-Milwaukee; we thank UWM for its support. Funding was provided by NSF Grant DEB-9209206, by Research Travel Contracts from the Oak Ridge Associated Universities under U.S. Department of Energy (DOE) Contract DEAC05-76OR00033, and by Forest Service Cooperative Agreement No. 29- 1280 (USFS-Savannah River and the Southern Research Station) under Interagency Agreement DE-IA09-76SR00056 with the DOE-Savannah River Operations Office. We thank J. Blake and J. Walker for supporting and facilitating the coop agreement. K. Kirkman, G. Guntenspergen, R. Sharitz,
A. Harrison, B. Collins, J. Mulhouse, and two anonymous reviewers provided helpful comments on the manuscript.

\section{LITERATURE CITED}

Bailey, R. G., P. E. Avers, T. King, and W. H. McNab. 1994. Ecore gions and subregions of the United States. US Department of Agriculture Forest Service, Washington, DC, USA.

Bedford, B. L. 1996. The need to define hydrologic equivalence at the landscape scale for freshwater wetland mitigation. Ecological Applications 6:57-68.

Bennett, S. H. and J. B. Nelson. 1991. Distribution and status of Carolina bays in South Carolina. South Carolina Wildlife and Marine Resources Department, Columbia, SC, USA. Nongame and Heritage Trust Publication No. 1.

Brinson, M. M. 1993. A hydrogeomorphic classification for wetlands. U.S. Army Engineer Waterways Experiment Station, Vicksburg. MS, USA. WRP-DE-4.

Brinson, M. M. and R. Rheinhardt. 1996. The role of reference wetlands in functional assessment and mitigation. Ecological Applications $6: 69-76$

Chmielewski, R. M. 1996. Hydrologic analysis of Carolina bay wetlands at the Savannah River Site, South Carolina. M.S. Thesis. University of Wisconsin-Milwaukee, Milwaukee, WI, USA.

Christensen, N. L. 1988. Vegetation of the Southeastern Coastal Plain. p. 317-363. In M. G. Barbour and W. D. Billings (eds.) North American Terrestrial Vegetation. Cambridge University Press, New York, NY, USA.

Clewell, A. F, and R. Lea. 1990. Creation and restoration of forested wetland vegetation in the southeastern United States. p. 195-231. In J. A. Kusler and M. E. Kentula (eds.) Wetland Creation and Restoration: the Status of the Science. Island Press, Covelo, CA, USA.

Collins, B. S. and L. L. Battaglia. 2001. Hydrology effects on propagule bank expression and vegetation in six Carolina bays. Community Ecology 2:2 1-33.

Doering, J. A. 1960. Quaternary surface formations of southern part of Atlantic Coastal Plain. Journal of Geology 6X: 1 X2-202.

Dufrêne, M. and P. Legendre. 1997. Species assemblage5 and indicator species: the need for a flexible asymmetric approach. Ecological Monographs 67:345-366.

Edwards, A. L. and A. S. Weakley. 2001. Population biology and management of rare plants in depression wetlands of the Southeastern Coastal Plain, USA. Natural Areas Journal 2 1: 12-35.

Environmental Law Institute 2001. Focus on SWANCC. National Wetlands Newsletter 23(2): I-17.

Ewel. K. C. 1998. Pondcypress swamps. p. 405 420. In M. G. Messina and W. H. Conner (eds.) Southern Forested Wetlands: Ecology and Management. Lewis Publishers, Boca Raton, FL. USA.

Folkerts, G. W. 1997. Citronelle ponds: little-known wetlands of the central Gulf Coastal Plain, USA. Natural Areas Journal 17:6-1 6.

Galatowitsch. S. M. and A. G. van der Valk. 1996. The vegetation of restored and natural prairie wetlands. Ecological Applications 6: $102-112$.

Godwin, K. S., J. P. Shallenberger, D. J. Leopold, and B. L. Bedford. 2002. Linking landscape properties to local hydrogcologic gradients and plant species occurrence in minerotropbic fens of New York State, USA: a hydrogeologic setting (HGS) framework. Wetlands 22:722-737

Gwin, S. E., M. E. Kentula, and P. W. Shaffer. 1999. Evaluating the effects of wetland regulation through hydrogeomorphic classification and landscape profiles. Wetlands 19:477-489.

Haukos. D. A. and L. M. Smith. 1994. Composition of seed banks along an elevational gradient in playa wetlands. Wctlnnds 14:301307.

Hendricks, E. L. and M. H. Goodwin. 1952. Water-level fluctuations in limestone sinks in southwestern Georgia. U.S. Geological Survey Water-Supply Paper 11 IO-E.

Jones, S. M., D. H. Van Lear, and S. K. Cox. 1984. A vegetationlandform classification of forest sites within the upper Coastal 
Plain of South Carolina. Bulletin of the Torrey Botanical Club $111: 349-360$.

Kantrud, H. A., J. B. Millar, and A. G. van der Valk. 1989. Vegetation of wetlands of the prairie pothole region. p. 132-I X7. In A. G. van der Valk (ed.) Northern Prairie Wetlands. Iowa State University Press, Ames, IA, USA.

Kirkman, L. K. 1995. Impacts of fires and hydrological regimes on vegetation in depression wetlands of southeastern USA. p. 10-20. In S. 1. Cerulean and R. T. Engstrom (eds.) Fire in wetlands: a management perspective. Proceedings of the $1^{\text {th }}$ Tall Timbers Fire Ecology Conference, Tall Timbers Research Station, Tallahassee, FL, USA.

Kirkman, L. K., M. B. Drew, L. T. West, and E. R. Blood. 199X. Ecotone characterization between upland longleaf pine/wiregrass stands and seasonally-ponded isolated wetlands. Wetlands IX: 346-364.

Kirkman, L. K., P. C. Goebel, L. West, M. B. Drew, and B. J. Palik. 2000. Depressional wetland vegetation types: a question of plant community development. Wetlands 20:373-385.

Kirkman, L. K., S. W. Golladay, L. Laclaire, and R. Sutter. 1999. Riodiversity in southeastern, seasonally ponded, isolated wetlands: management and policy perspectives for research and conservation. Journal of the North American Benthological Society 18: 553-562.

Kirkman, L. K., R. F. Lide, G. Wein, and R. R. Sharitz. 1996. Vegetation changes and land-use legacies of depression wetlands of the western Coastal Plain of South Carolina: 195 I-1992. Wetlands 16:564-576.

Lide, R. F. 1997. When is a depression wetland a Carolina bay? Southeastern Geographer 37:90-98.

Lide, R. F., V. G. Meentemeyer. J. E. Pinder III, and L. M. Beatty. 1995. Hydrology of a Carolina bay located on the Upper Coastal Plain of western South Carolina. Wetlands 15:47-57.

McCune, B. and J. B. Grace 2002. Analysis of Ecological Communities. MjM Software Design, Gleneden Beach, OR, USA.

McCune, B. and M. J. Mefford. 1995. PC-ORD. Multivariate Analysis of Ecological Data, Version 2.0. MjM Software Design, Gleneden Beach, OR, USA.

Myers, R. K., R. Zahner, and S. M. Jones. 1986. Forest Habitat Regions of South Carolina from Landsat Imagery. Clemson University, Clemson, SC, USA. Forest Research Series No. 42.

National Ocean and Atmospheric Administration, 1993-1 996. Climatological data for South Carolina, 1993-1 996. National Climatic Data Center, Asheville, NC, USA.

Nifong, T. D. 199X. An ecosystematic analysis of Carolina bays in the Coastal Plain of the Carolinas. Ph.D. Dissertation. University of North Carolina, Chapel Hill, NC, USA.

Nystrom, P. G. Jr., R. H. Willoughby, and L. E. Kite. 1986. Cretaceous-Tertiary stratigraphy of the upper edge of the Coastal Plain between North Augusta and Lexington, South Carolina. South Carolina Geological Survey, Columbia, SC, USA.

Palik. B. J., P. C. Goebel, L. K. Kirkman, and I.. West. 2000. Using landscape hierarchies to guide restoration of disturbed ecosystems. Ecological Applications 10: 1 X9-202.

Pechmann, J. H. K., D. E. Scott, J. W. Gibbons, and R. D. Semlitsch. 1989. Influence of wetland hydroperiod on diversity and abundance of metamorphosing juvenile amphibians. Wetlands Ecology and Management $1: 3-11$

Peet. R. K. 1980. Ordination as a tool for analyzing complex data sets. Vegctatio 42: 17 1-1 74.

Pickett, S. T. A. and V. T. Parker. 1994. Avoiding the old pitfalls: opportunities in a new discipline. Restoration Ecology 2:75-79.

Poiani, K. A. and P. M. Dixon. 1995. Seed banks of Carolina bays: potential contributions from surrounding landscape vegetation. American Midland Naturalist 135: 140-I 54.

Poiani, K. A. and W. C. Johnson. 1991. Global warming and prairie wetlands. Bioscience 41:61 1-61X.

Porcher, R. D. 1966. A Aoristic study of the vascular plants in nine selected Carolina bays in Berkeley County, South Carolina. M.S. Thesis. University of South Carolina, Columbia, SC, USA.

Prowell, D. C. 1994. Preliminary geologic map of the Barnwell 30' $X$ 60' quadrangle, South Carolina and Georgia. U.S. Geological Survey Open-File Report 94-673.
Rader, R. B. and D. K. Shiozawa. 2001. General principles of establishing a bioassessment program. p. 13-43. In R. B. Rader, D. P. Batzer, and S. A. Wissinger (eds.) Bioassessment and Management of North American Freshwater Wetlands. John Wiley and Sons, New York, NY, USA.

Reed, P. B., Jr. 1988. National list of plant species that occur in wetlands: national summary. U.S. Fish and Wildlife Service, Washington, DC, USA. Biological Report 88(24).

Schalles, J. F., R. R. Sharitz, J. W. Gibbons, G. J. Leversee, and J. N. Knox. 19X9. Carolina Bays of the Savannah River Plant. US Department of Energy Savannah River Plant, National Environmental Research Park Program, Aiken, SC, USA. SRONERP-IX.

Schalles, J. F. and D. J. Shure. 19X9. Hydrology, community structure, and productivity patterns of a dystrophic Carolina bay wetland. Ecological Monographs 59:365-385.

Semlitsch, R. D. and J. R. Bodie. 199X. Are small, isolated wetlands expendable? Conservation Biology 12: 1129-1 133.

Sharitz, R. R. and C. A. Gresham. 199X. Pocosins and Carolina bays, p. 343-377. In M. G. Messina and W. H. Conner (eds.) Southern Forested Wetlands: Ecology and Management. Lewis Publishers, Boca Raton, FL, USA.

Singer, J. H. 2001. Effects of overstory removal and fire on wetland vegetation and recruitment from the seedbank in a hydrologically restored Carolina bay wetland. M.S. Thesis. University of Georgia, Athens, GA, USA.

Smith, R. D., A. Ammann, C. Bartoldus, and M. M. Brinson. 1995. An approach for assessing wetland functions using hydrogeomorphic classification, reference wetlands, and functional indices. U.S. Army Engineer Waterways Experiment Station, Vicksburg, MS, USA. WRP-DE-O.

Snodgrass, J. W., M. J. Komoroski, A. L. Bryan, Jr., and J. Burger. 2000. Relationships among isolated wetland size, hydroperiod, and amphibian species richness: implications for wetland regulations. Conservation Biology 14:414 419.

Soil Survey Staff 1975. Soil Taxonomy. US Department of Agriculture, Washington, DC, USA. Handbook 436.

Stewart, R. E. and H. A. Kantrud. 1971. Classification of natural ponds and lakes in the glaciated prairie region. U.S. Bureau of Sport Fisheries and Wildlife, Washington, DC, USA. Resource Publication 92.

Sun, G., S. G. McNulty, J. P. Shepard, D. M. Amatya, H. Riekerk, N. B. Comerford, W. Skaggs, and L. Swift, Jr. 2001. Effects of timber management on the hydrology of wetland forests in the southern United States. Forest Ecology and Management 143: 227-236.

Tangen, B. A.. M. G. Butler, and M. J. Ell. 2003. Weak correspondence between macroinvertebrate assemblages and land use in Prairie Pothole Region wetlands, USA. Wetlands 23: 104-1 IS.

Taylor, B. E., D. A. Leeper, M. A. McClure, and A. E. DeBiase, 1999. Carolina bays: ecology of aquatic invertebrates and perspectives on conservation. p. 167-195. In D. P. Batzer, R. B. Rnder, and S. A. Wissinger (eds.) Invertebrates in Freshwater Wetlands of North America: Ecology and Management. John Wiley \& Sons, Inc., New York, NY, USA.

ter Braak. C. J. F. 1993. CANOCO-a FORTRAN Program fol Canonical Community Ordination. Version 3.12. Microcomputer Power, Ithaca, NY, USA.

ter Braak. C. J. F. 1995. Ordination. p. 91-173. In R. H. G. Jongman, C. J. F. ter Braak, and O, F. R. van Tongeren (cds.) Data Analysis in Community and Landscape Ecology. Cambridge University Press. Cambridge, England.

van der Valk, A. G. and C. B. Davis. 1978. The role of seed banks in the vegetation dynamics of prairie glacial marshes. Ecology 59: $322-335$.

Weakley, A. S. and M. P. Schafale. 1990. Classification of the natural communities of North Carolina. Third approximation. North Carolina Natural Heritage Program, Department of Environment, Health, and Natural Resources, Raleigh, NC, USA.

Wear, D. N. and J. G. Greis. 2002. Southern Forest Resource Assessment: summary of tindings. Journal of Forestry 100(7): 6-14.

Whipple, S. A., L. II. Wellman, and B. J. Good. 1981. A classifi- 
cation of hardwood and swamp forests on the Savannah River Plant, South Carolina. U.S. Department of Energy Savannah River Plant, National Environmental Research Park Program, Aiken, SC, USA. SRO-NERP-6.

Wilcox, D. A., J. E. Meeker, P. L. Hudson, B. J. Armitage, M. G Black, and D. G. Uzarski. 2002. Hydrologic variability and the application of index of biotic integrity metrics to wetlands: a Great Lakes evaluation. Wetlands 22:588-615.

Workman, S. W. and K. W. McLeod. 1990. Vegetation of the Sa- vannah River Site: major community types. U.S. Department of Energy Savannah River Site, National Environmental Research Park Program, Aiken, SC, USA. SRO-NERP-19.

Zar, J. H. 1999. Biostatistical Analysis, fourth edition. Prentice Hall, Upper Saddle River, NJ, USA.

Manuscript received 5 August 2002; revisions received 30 April 2003, 23 June 2003, and 25 August 2003; accepted 11 November 2003 . 
Appendix 1. Mean (SE) percent abundances (frequencies) of common plant species in six Upper Coastal Plain depression wetland types. Significant indicator species for one or more types are noted by *, and the associated abundances are highlighted in boldface.

\begin{tabular}{|c|c|c|c|c|c|c|c|}
\hline \multirow[b]{2}{*}{ Species } & \multirow[b]{2}{*}{$\begin{array}{l}\text { Wetland } \\
\text { Indicator }\end{array}$} & \multicolumn{6}{|c|}{ Wetland Type } \\
\hline & & $\begin{array}{c}\text { Open-Water } \\
\text { Pond }\end{array}$ & $\begin{array}{c}\text { Grass } \\
\text { Marsh }\end{array}$ & $\begin{array}{l}\text { Depression } \\
\text { Meadow }\end{array}$ & $\begin{array}{c}\text { Sedge } \\
\text { Marsh/Meadow }\end{array}$ & $\begin{array}{l}\text { Swamp } \\
\text { Forest }\end{array}$ & $\begin{array}{l}\text { Bottomland } \\
\text { Hardwoods } \\
\text { Forest }\end{array}$ \\
\hline Acer rubrum L.* & FAC or OBL & $5(1)$ & $8(4)$ & $3(0)$ & $13(6)$ & $7(2)$ & $29(8)$ \\
\hline Brasenia schreberi Gmel. & OBL & $20(7)$ & $7(4)$ & $16(10)$ & 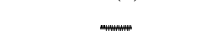 & $1(1)$ & - \\
\hline Campsis radicans (L.) Seem.* & FAC & $\ldots$ & - & - & $\stackrel{n}{\min }$ & 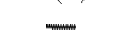 & $23(8)$ \\
\hline Carex striata Michx.* & OBL & 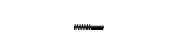 & - & & $71(6)$ & 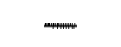 & 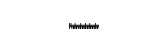 \\
\hline Cephalanthus occidentalis $\mathrm{L}$. & OBL & $16(6)$ & $26(6)$ & $6(3)$ & $2(1)$ & $7(3)$ & $13(4)$ \\
\hline Diospyros virginiana $\mathrm{L}$. & FAC & $2(2)$ & $6(4)$ & $21(9)$ & $2(1)$ & $4(2)$ & $12(5)$ \\
\hline Eleocharis acicularis (L.) R.\&S.* & OBL & & - & $17(9)$ & & & $2(1)$ \\
\hline Eleocharis equisitoides (E11.) Torr.* & OBL & $21(10)$ & $5(0)$ & - & $3(0)$ & $2(0)$ & $\ldots$ \\
\hline Eleocharis melanocarpa Torr* & FACW & $5(2)$ & $3(2)$ & $29(10)$ & - & $2(1)$ & 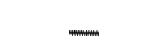 \\
\hline Leersia hexandra Sw.* & OBL & $18(7)$ & $31(9)$ & $54(10)$ & - & $15(6)$ & $15(12)$ \\
\hline Liquidambar styraciflua $\mathrm{L} . *$ & $\mathrm{FAC}+$ & $4(2)$ & $18(5)$ & $11(3)$ & $12(5)$ & $18(5)$ & $67(6)$ \\
\hline Ludwigia sphaerocarpa EII. & OBL & $10(5)$ & $6(2)$ & $37(19)$ & $6(5)$ & - & - \\
\hline Nymphaca odorata $\wedge$ it * & OBL & $58(7)$ & - & $1(1)$ & $2(2)$ & $8(6)$ & $3(0)$ \\
\hline Nyssa biflora Walt.* & OBL & $16(5)$ & $20(5)$ & $3(1)$ & $31(10)$ & $64(10)$ & $12(5)$ \\
\hline Nyssa sylvatica Marsh.* & FAC & $3(2)$ & - & $4(0)$ & $5(3)$ & $7(2)$ & $12(6)$ \\
\hline Panicum hemitomon Schult.* & OBL & $25(7)$ & $57(10)$ & $24(9)$ & $12(6)$ & $13(11)$ & - \\
\hline Panicum verrucosum Muhl. & FACW & $7(2)$ & $19(12)$ & $23(6)$ & - & $63(0)$ & $20(6)$ \\
\hline Pinus taeda L., P. elliottii Engelm. & FAC, FACW & $6(3)$ & $26(7)$ & $7(2)$ & $11(7)$ & $12(10)$ & $12(4)$ \\
\hline Polygonum hydropiperoides Michx. & OBL & $1(1)$ & $8(3)$ & $17(5)$ & & - & $14(4)$ \\
\hline Pontederia lanceolata Nuttall: & OBL & $37(17)$ & $20(11)$ & & $22(12)$ & & (1) \\
\hline Proserpinaca spp. & OBL & $5(2)$ & $5(4)$ & $19(7)$ & $2(1)$ & $7(7)$ & $1(1)$ \\
\hline Rhexia spp.* & FACW+ & $2(1)$ & $16(9)$ & $8(3)$ & 1 (1) & - & $1(1)$ \\
\hline Smilax rotundifolia L.* & FAC & & $5(2)$ & $6(4)$ & $3(1)$ & $3(1)$ & $16(5)$ \\
\hline Sphagnum spp.** & (OBL) & & $45(19)$ & $5(5)$ & $3(2)$ & & $5(5)$ \\
\hline Taxodium ascendans Brogngn., T. distichum (L.) Rich.* & $\mathrm{OBL}$ & $23(2)$ & $25(19)$ & - & $55(0)$ & $52(13)$ & $17(8)$ \\
\hline Number of wetlands & & 10 & 9 & 13 & 5 & 6 & 13 \\
\hline
\end{tabular}


Appendix 2. Soil chemistry for depression wetland soils of different textural classes. All elements except N are in kg/ha. ANOVA tests of differences between soil classes are noted as significant $\left(^{*}\right)$ at $\mathrm{P} \leq 0.05$. marginal $(\dagger)$ at $\mathrm{P} \leq 0.10$, or not significant $(\mathrm{n} . \mathrm{s}$.). $\mathrm{n}=$ number of samples.

\begin{tabular}{|c|c|c|c|}
\hline & \multicolumn{2}{|c|}{ Soil Textural Class } & \multirow{2}{*}{$\begin{array}{c}\text { Significance } \\
\text { of Soil Type } \\
\text { Differences }\end{array}$} \\
\hline & Clayey ${ }^{a}$ & Sandy" & \\
\hline \multicolumn{4}{|c|}{ Topsoil $(0-15 \quad \mathrm{~cm})$ : } \\
\hline $\mathrm{pH}$ & $4.6 \quad(0.05)$ & $4.7 \quad(0.06)$ & n.s. \\
\hline total $\mathrm{N}(\%)$ & $0.44(0.07)$ & $0.23(0.03)$ & \\
\hline total $\mathrm{P}$ & $11.9(1.2)$ & $12.1(1.8)$ & n.s. \\
\hline total $\mathrm{K}$ & 51.8 (4.7) & 49.7 (6.6) & n.s. \\
\hline total $\mathrm{Ca}$ & 279 & $276(76)$ & n.s. \\
\hline total $\mathrm{Mg}$ & $60.1 \quad(6.8)$ & $53.6 \quad(17.2)$ & $\grave{t}$ \\
\hline $\mathrm{n}$ & 35 & 22 & \\
\hline \multicolumn{4}{|c|}{ Subsoil $(61-76 \mathrm{~cm})$ : } \\
\hline $\mathrm{pH}$ & $4.8 \quad(0.04)$ & $5.0 \quad(0.04)$ & \\
\hline total $\mathrm{N}(\%)$ & $0.03(0.004)$ & $0.02(0.002)$ & \\
\hline total $\mathrm{P}$ & $9.0 \quad(1.8)$ & $5.0 \quad(1.1)$ & n.s. \\
\hline total $\mathrm{K}$ & $40.0 \quad(5.3)$ & $32.6(7.0)$ & $\mathrm{n}, \mathrm{s}$. \\
\hline total $\mathrm{Ca}$ & $383(68)$ & $258(55)$ & \\
\hline total $\mathrm{Mg}$ & $92.6 \quad(10.1)$ & $56.0 \quad(10.6)$ & $*$ \\
\hline $\mathrm{n}$ & 33 & 20 & \\
\hline
\end{tabular}

Rembert, Coxville, and McColl series.

b Ogeechee, Williman, Pelham, and Plummer series. 